\title{
KONCEPCJA REPOZYTORIUM DOBRYCH PRAKTYK WYKORZYSTYWANYCH W PUBLICZNYM ZARZADDZANIU KRYZYSOWYM
}

\section{Wprowadzenie}

$\mathrm{P}$ ojęcie zarządzania kryzysowego jest rozpatrywane na gruncie kilku dyscyplin naukowych - nauk o administracji, nauk o bezpieczeństwie, nauk o zarządzaniu, ekonomii oraz finansów - w ujęciach specyficznych dla tych dyscyplin. „Zarządzanie kryzysowe to działalność organów administracji publicznej będąca elementem kierowania bezpieczeństwem narodowym, która polega na zapobieganiu sytuacjom kryzysowym, przygotowaniu do przejmowania nad nimi kontroli $\mathrm{w}$ drodze zaplanowanych działań, reagowaniu w przypadku wystąpienia sytuacji kryzysowych, usuwaniu ich skutków oraz odtwarzaniu zasobów i infrastruktury krytycznej" (Ustawa, 2007, art. 2). Określenie publiczne zarządzanie kryzysowe odnosi się do logistyki społecznej, a w jej ramach do zapewniania bezpieczeństwa publicznego (Zawiła-Niedźwiecki, Kisilowski, 2016).

Unijny Mechanizm Ochrony Ludności - UMOL (Dz. Urz. UE L 347/924) nakłada na państwa członkowskie Unii Europejskiej obowiązek zarządzania ryzykiem. Jest on rozumiany jako „umiejętność państwa członkowskiego lub jego regionów zmniejszenia ryzyka, dostosowania się do ryzyka lub ograniczenia ryzyka, w szczególności jego skutków i prawdopodobieństwa klęski lub katastrofy zidentyfikowanego $\mathrm{w}$ przeprowadzonej przez to państwo lub regiony ocenie ryzyka do poziomu akceptowanego $\mathrm{w}$ tym państwie członkowskim" (UMOL, art. 4 ust. 8). Jednak proces wdrażania tej decyzji Parlamentu Europejskiego przebiega $\mathrm{z}$ oporami. Brakuje metod dostosowanych do potrzeb administracji, dobrych praktyk i edukacji urzędników (Skomra, 2017).

Wprawdzie zarządzanie kryzysowe coraz częściej sięga do dorobku nauk o zarządzaniu, wykorzystując dobre praktyki wypracowane na potrzeby różnych subdyscyplin zarządzania, ale brakuje uporządkowania i usystematyzowania wiedzy na temat dobrych praktyk możliwych do zaadaptowania do publicznego zarządzania kryzysowego. Dlatego za cel niniejszej pracy przyjęto opracowanie koncepcji repozytorium dobrych praktyk obecnie wykorzystywanych i możliwych do wykorzystania $w$ publicznym zarządzaniu kryzysowym.

Wyniki badań przedstawione $\mathrm{w}$ artykule stanowią rezultat projektu rozwojowego prowadzonego przez autorów - pracowników Wydziału Zarządzania Politechniki Warszawskiej ${ }^{1}$. W toku badań zidentyfikowano zbiory dobrych praktyk możliwych do wykorzystania $\mathrm{w}$ publicznym zarządzaniu kryzysowym oraz opracowano wymiary klasyfikacji dobrych praktyk, które posłużyły do budowy koncepcji repozytorium dobrych praktyk. Biorąc pod uwagę, że w Polsce jest ponad 2800 jednostek samorządu terytorialnego (2477 gmin i 380 powiatów) zobowiązanych do realizacji ustawowych obowiązków związanych $\mathrm{z}$ oceną ryzyka i sporządzaniem planów zarządzania kryzysowego, opracowane repozytorium może zwrócić uwagę pracowników tych jednostek na instrumentarium dobrych praktyk możliwych do wykorzystania podczas przygotowywania tych dokumentów.

\section{Dobre praktyki w zarządzaniu}

D obre praktyki towarzyszą działaniom podejmowanym przez organizacje we wszystkich obszarach zarządzania. Stanowią one dorobek nauk o zarządzaniu, wypracowany przez naukowców i praktyków w celu poprawy skuteczności i efektywności funkcjonowania organizacji. Z. Martyniak (1996) określa je mianem narzędzi organizowania, przy czym podkreśla, że metody "nie stanowią zastygłych sposobów postępowania. Przeciwnie - nieustannie się rozwijają", zaś główną tendencją ich ewolucji jest przechodzenie od metod ogólnych (elastycznych i mało spójnych) do metod szczegółowych, a w końcu do programów dających się stosować automatyczne (s. 46-47), które Z. Mikołajczyk (2001, s. 39) utożsamia $\mathrm{z}$ technikami.

W okresie ponad 100 lat rozwoju naukowego zarządzania następował coraz szybszy przyrost narzędzi wykorzystywanych w różnych dziedzinach zarządzania. Są one nazywane "dobrymi praktykami”. Zgodnie z definicją przedstawioną w publikacji (Cyfert, Szumowski, 2015, s. 39), przez „dobre praktyki” należy rozumieć metody i koncepcje zarządzania służące doskonaleniu organizacji. W Słowniku Języka Polskiego słowo „praktyka” oznacza świadome, celowe działanie wykonywane regularnie bądź też umiejętności zdobyte dzięki takiemu działaniu (https://sjp.pwn.pl/szukaj/praktyka. html). Dobra praktyka oznacza zatem sposób realizacji 
określonego działania, który powinien charakteryzować się powtarzalnością oraz prowadzić do zwiększenia wiedzy, umiejętności i doświadczenia osoby ją wykorzystującej. Dobre praktyki określają najlepszy znany sposób realizacji zadań, prowadzący do osiągania założonych przez organizację rezultatów (Karwińska, Wiktor, 2008, s. 6-8).

Definicja „dobrej praktyki” jest na tyle szerokim pojęciem, że obejmuje zarówno znane i powszechnie stosowane metody i techniki (sposoby postępowania w rozwiązywaniu problemów), różnego rodzaju dokumenty i procedury (opisujące wytyczne, założenia), jak i zasady, którymi należy się kierować przy realizacji danego działania (Kąkol, Smagowicz, 2018), a także zestawy konkretnych działań prowadzących do skutecznego rozwiązania pewnego problemu, możliwych do wykorzystania w określonej sytuacji, a wiedza ta jest czerpana $z$ dotychczasowych doświadczeń i obserwacji (Wiśniewski i in., 2017), przy czym z upływem czasu mogą się one stać uznanym i akceptowanym wzorcem, czyli metodą lub techniką. Niniejsze opracowanie skupia się przede wszystkim na dobrych praktykach rozumianych jako uznane metody i techniki stosowane w rozwiązaniu problemów z obszaru organizacji i zarządzania, w tym przypadku - zarządzania kryzysowego.

Klasyfikacje dobrych praktyk stosowanych $\mathrm{w}$ różnych obszarach zarządzania są $\mathrm{w}$ większości przypadków jednowymiarowe, tzn. dokonują podziału według jednego kryterium, na przykład klasyfikacja metod poprawy produktywności wykorzystująca jako kryterium klasyfikacji główne etapy cyklu organizacyjnego Le Châteliera (Lis, 1999, s. 120); (Kosieradzka, 2012, s. 50-51) czy klasyfikacja narzędzi koncepcji Six Sigma, przyporządkowująca zestawy metod i technik do poszczególnych etapów cyklu DMAIC (Define, Measure, Analyze, Improve, Control) - (Lunau, 2008). K. Szczepańska (2009, s. 64-71) przedstawia klasyfikację metod i technik wykorzystywanych w koncepcji TQM w kilku przekrojach klasyfikacyjnych, ale nie są one wzajemnie powiązane.

Pojęcie dobrych praktyk jest nierozerwalnie związane $\mathrm{z}$ koncepcją benchmarkingu. Pionier benchmarkingu R. Camp (1989, s. 28) definiuje benchmarking jako „poszukiwanie najlepszych praktyk dla danej działalności, które prowadzą do osiągania wyjątkowych wyników”. Ch.E. Bogan i M.J. English (1994, s. 241-245) podkreślają, że „efektywne wykorzystywanie najlepszych praktyk jest wyzwaniem herkulesowym, znacznie trudniejszym niż poszukiwanie i gromadzenie informacji benchmarkingowych". Uważają, że jedynym rozwiązaniem prowadzącym do zwiększenia wykorzystywania dobrych praktyk jest centralna baza danych, wsparta odpowiednimi rozwiązaniami software'owymi.

Żeby ułatwić korzystanie z rozrastającego się zbioru metod, technik, procedur i wzorców uznawanych za dobre praktyki, w różnych dziedzinach zaczęto tworzyć repozytoria dobrych praktyk. Słownik Języka Polskiego (https://sjp.pl/repozytorium) definiuje repo- zytorium jako „ogólnodostępne pomieszczenie, służące do przechowywania dokumentów, które są wydawane na każde żądanie". Bardziej współczesną definicję repozytorium podaje Wikipedia (https://pl.wikipedia. org/wiki/Repozytorium): „miejsce uporządkowanego przechowywania dokumentów, z których wszystkie przeznaczone są do udostępniania. Dziś termin stosowany jest również w odniesieniu do najrozmaitszych zasobów cyfrowych (baz danych, zbioru pakietów czy kodów źródłowych), np. w Internecie". Jako przykłady repozytoriów dobrych praktyk stosowanych w zarządzaniu można podać:

- Repozytorium dobrych praktyk w modelu dojrzałości zarządzania projektami OPM3 (Organizational Project Management Maturity Model), liczące 586 dobrych praktyk, sklasyfikowanych $\mathrm{w}$ dwóch przekrojach: poziomów zarządzania (zarządzanie projektem, zarządzanie programem, zarządzanie portfelem projektów) i poziomu dojrzałości procesów zarządzania (poziom standaryzowany, mierzony, sterowany i ciągle doskonalony) (PMI, 2003, s. 90-122);

- Repozytorium dobrych praktyk w zintegrowanym modelu dla zarządzania procesowego wytwarzaniem oprogramowania CMMI (Capability Maturity Model Integration), zawierające kilkaset praktyk sklasyfikowanych w trzech przekrojach: czterech dziedzin (zarządzanie procesem, zarzadzanie projektem, projektowanie oraz wsparcie), obszarów procesowych wyodrębnionych w ramach każdej dziedziny (odpowiednio 5, 8, 6 i 6 - łącznie 25 obszarów) i poziomów dojrzałości procesowej (procesy wykonywane, procesy zarządzanie, procesy zdefiniowane, procesy mierzone i procesy ciągle doskonalone) (Chrissis i in., 2003, s. 55-84);

- Rejestr dobrych praktyk (około 350 praktyk), opracowany w ramach modelu BPMM (Business Process Maturity Model) przez międzynarodową organizację Object Management Group (OMG, 2008).

W modelu CMMI pojawia się dodatkowe rozróżnienie dobrych praktyk na praktyki ogólne, czyli praktyki, które są wspólne dla wielu obszarów procesowych, oraz praktyki specyficzne, które odnoszą się tylko do jednego obszaru procesowego (Chrapko, 2010, s. 10).

Celem niniejszego artykułu jest zaproponowanie struktury repozytorium dobrych praktyk do zastosowania w obszarze publicznego zarządzania kryzysowego. Repozytorium powinno umożliwić na podstawie zadanych kryteriów (np. celu zastosowania, wymiaru terytorialnego czy etapu zarządzania ryzykiem) identyfikację zestawu metod i technik wspomagających i ułatwiających realizację różnych zadań z obszaru publicznego zarządzania kryzysowego.

\section{Dobre praktyki w zarządzaniu kryzysowym}

W

obszarze publicznego zarządzania kryzysowego obowiązują przepisy regulujące działania podej- 
mowane przez poszczególne jednostki administracji publicznej, jednakże $\mathrm{w}$ przepisach tych istnieje duża dowolność w zakresie doboru metod i technik stosowanych do osiągania celów wyznaczonych w ramach procesów planowania cywilnego i zarządzania kryzysowego (Tyburska, 2009, s. 96; Krupa, Wiśniewski, 2015, s. 94; Lidwa, 2015, s. 165-176). Z jednej strony działania prowadzone $\mathrm{w}$ ramach obydwu procesów są obarczone dużą odpowiedzialnością za bezpieczeństwo narodowe, a jednocześnie $\mathrm{z}$ drugiej strony nie została zdefiniowana baza wiedzy klasyfikująca narzędzia wspomagające ich realizację.

W wyniku badań prowadzonych w ramach projektów badawczo-rozwojowych $\mathrm{w}$ obszarze publicznego zarządzania kryzysowego zidentyfikowano szereg narzędzi specyficznych, dedykowanych do zastosowania $\mathrm{w}$ rozwiązywaniu problemów związanych $\mathrm{z}$ publicznym zarządzaniem kryzysem, jak również koncepcji, metod i technik ogólnych, stosowanych w różnych obszarach zarządzania, możliwych do wykorzystania w zarządzaniu kryzysowym (Kosieradzka, Zawiła-Niedźwiecki, 2016, s. 85-140; Kąkol, Smagowicz, 2018). W celu identyfikacji najlepszych praktyk dedykowanych dla publicznego zarządzania kryzysowego skorzystano z opracowań, zawierających klasyfikacje narzędzi stosowanych w różnych obszarach nauk o zarządzaniu. Były to przede wszystkim:

- klasyfikacja metod i technik organizatorskich (Lis, 1999),

- klasyfikacja metod stosowanych w procesie oceny ryzyka (ISO 31010),

- klasyfikacja norm i standardów z zakresu zarządzania ryzykiem (Kosieradzka, Zawiła-Niedźwiecki, 2016, s. 19-34),

- klasyfikacja metod wykorzystywanych w procesie foresightu, dedykowanych do wykorzystania w procesie zarządzania ryzykiem (Skomra, 2015, s. 48-81),

- klasyfikacja metod twórczego myślenia (Kosieradzka, 2013),

- wykaz dobrych praktyk stosowanych w metodykach zagranicznych (Ostrowska, Wiśniewski, 2016, s. 111-123).

Grupy dobrych praktyk zidentyfikowane na podstawie literatury i wiedzy ekspertów uczestniczących $\mathrm{w}$ projekcie przedstawiono $\mathrm{w}$ tabeli 1 . Należy podkreślić, że tak uporządkowane repozytorium dobrych praktyk jest bezużyteczne dla użytkownika, który nie posiada głębokiej wiedzy i doświadczenia w realizacji zadań wchodzących w skład zarządzania kryzysowego, stąd pojawiła się konieczność opracowania metodycznej struktury repozytorium.

\section{Metody badawcze i założenia do budowy repozytorium dobrych praktyk dla publicznego zarządzania kryzysowego}

C

elem zadania badawczego było uporządkowanie zbioru dobrych praktyk, scharakteryzowanego powyżej, w sposób ułatwiający szybki dobór odpowiednich narzędzi wspomagających realizację różnych zadań z obszaru zarządzania kryzysowego, a w szczególności identyfikacji, analizy i oceny ryzyka oraz sporządzania planów zarządzania kryzysowego i planów ratowniczych. Jako sposób osiągnięcia tego celu przyjęto opracowanie koncepcji repozytorium dobrych praktyk dla publicznego zarządzania kryzysowego. Badania miały charakter jakościowy, wykorzystano w nich następujące metody badawcze: badania literaturowe, analizę aktów prawnych, badania planów zarządzania kryzysowego w wybranych jednostkach administracji terytorialnej, badanie opinii ekspertów oraz studia przypadków.

Badania literaturowe prowadzone były na publikacjach pochodzących $\mathrm{z}$ baz Web of Science oraz Scopus. Ich celem było stwierdzenie, jakie metody i techniki są wykorzystywane w publicznym zarządzaniu kryzysowym w różnych krajach, między innymi w Niemczech, Szwecji, Kanadzie, Irlandii, Wielkiej Brytanii i Holandii oraz jaką strukturę mają repozytoria dobrych praktyk wykorzystywane w różnych obszarach zarządzania (np. Internetowy System Aktów Prawnych, EUR-Lex, Standardy Zarządzania Zasobami Ludzkimi, Repozytorium Dobrych Praktyk systemu ePUAP, Centralne Repozytorium Wzorów Dokumentów Elektronicznych, Baza dobrych praktyk Ministerstwa Gospodarki Morskiej i Rozwoju Wsi itp.). Analiza aktów prawnych obejmowała uwarunkowania formalnoprawne dla procesu zarządzania kryzysowego i planowania cywilnego w Polsce oraz przepisy Unii Europejskiej, z którymi polskie akty prawne muszą być zgodne np. przepisy dotyczące Unijnego Mechanizmu Ochrony Ludności. Badanie planów zarządzania kryzysowego sporządzanych przez wybrane jednostki administracji terytorialnej $\mathrm{z}$ wykorzystaniem metody porównania miało na celu ustalenie stopnia zgodności struktury planów między sobą oraz zakresu wykorzystywanych narzędzi wspomagających (dobrych praktyk).

Celem badania opinii ekspertów było pozyskanie rekomendacji dobrych praktyk wykorzystywanych w różnych obszarach zarządzania pod kątem ich przydatności w zarządzaniu kryzysowym oraz weryfikacja ustalonych wymiarów projektowanego repozytorium. Ekspertami byli samodzielni pracownicy naukowi w dyscyplinie nauk o zarządzaniu, a metodą pozyskania ich opinii był wywiad bezpośredni.

Studia przypadków polegały na przeprowadzeniu wywiadów kwestionariuszowych w czterech jednostkach administracji terytorialnej $\mathrm{w}$ celu weryfikacji stosowanych przez te podmioty dobrych praktyk oraz oceny przydatności zaprojektowanego repozytorium do poprawy kompetencji pracowników odpowiedzialnych w tych jednostkach za zarządzanie ryzykiem, a także za sporządzanie planów zarządzania kryzysowego i planów ratowniczych.

Koncepcja repozytorium dobrych praktyk na potrzeby publicznego zarządzania kryzysowego opiera 
Tabela 1. Dobre praktyki zaadaptowane do zarządzania kryzysowego

\begin{tabular}{|c|c|}
\hline Grupa praktyk & Przykłady praktyk \\
\hline Akty prawne & $\begin{array}{l}\text { Ustawy, np. Ustawa o zarządzaniu kryzysowym } \\
\text { Rozporządzenia, np. Rozporządzenia Rady Ministrów } \\
\text { w sprawie planów ochrony infrastruktury publicznej } \\
\text { Zarządzenia, np. Zarządzenia Prezesa Rady Ministrów } \\
\text { w sprawie wykazu przedsięwzięć i procedur systemu } \\
\text { zarządzania kryzysowego }\end{array}$ \\
\hline Normy i standardy & $\begin{array}{l}\text { ISO } 31010 \\
\text { BSI - Threat Catalogues } \\
\text { ISO } 13335-3\end{array}$ \\
\hline $\begin{array}{l}\text { Ogólnokrajowa dokumentacja } \\
\text { z zakresu zarządzania ryzykiem }\end{array}$ & $\begin{array}{l}\text { Strategia Bezpieczeństwa Narodowego RP } \\
\text { Krajowy Plan Zarządzania Kryzysowego } \\
\text { Narodowy Program Ochrony Infrastruktury Krytycznej }\end{array}$ \\
\hline Metody ciągłego doskonalenia & $\begin{array}{l}\text { Kaizen } \\
5 S \\
\text { Standaryzacja dokumentów }\end{array}$ \\
\hline $\begin{array}{l}\text { Metody wykorzystywane w procesach } \\
\text { foresightu }\end{array}$ & $\begin{array}{l}\text { metoda SWOT } \\
\text { mapowanie interesariuszy } \\
\text { debata publiczna }\end{array}$ \\
\hline Metody oceny ryzyka & $\begin{array}{l}\text { analiza drzewa zdarzeń } \\
\text { analiza scenariuszowa } \\
\text { analiza „co jeśli?” }\end{array}$ \\
\hline Metody organizatorskie & $\begin{array}{l}\text { ankieta } \\
\text { wywiad } \\
\text { lista pytań kontrolnych }\end{array}$ \\
\hline Metody twórczego myślenia & $\begin{array}{l}\text { burza mózgów } \\
\text { mapa myśli } \\
\text { diagram Ishikawy }\end{array}$ \\
\hline Metody statystyczne & $\begin{array}{l}\text { analiza Markova } \\
\text { analiza Bayesa } \\
\text { symulacja Monte Carlo }\end{array}$ \\
\hline Metody zarządzania jakością & $\begin{array}{l}\text { FMEA } \\
\text { Cykl Deminga PDCA + SDCA }\end{array}$ \\
\hline Zasady z metodyk międzynarodowych & $\begin{array}{l}\text { Analizy średnio- i długoterminowe (5-25 lat) } \\
\text { Podział zbudowanych scenariuszy na realne i rozwojowe } \\
\text { Uwzględnienie trendów zagrożeń tj.: osłabienie, nasilenie, } \\
\text { stabilizacja }\end{array}$ \\
\hline
\end{tabular}

Źródło: opracowanie własne

się na dwóch filarach. Jednym $\mathrm{z}$ nich jest tzw. metryka opisu dobrej praktyki, a drugim - wieloprzekrojowa klasyfikacja zbioru dobrych praktyk. Każda praktyka została scharakteryzowana w ujednolicony sposób, obejmujący:

- nazwę praktyki,

- opis praktyki oraz możliwych zastosowań,

- etapy i procedurę stosowania,

- narzędzia wspomagające (np. komputerowe),

- wymagania wstępne,

- odwołania do źródeł omawiających metodę,
- przynależność danej metody do poszczególnych klasyfikacji, przedstawionych poniżej,

- ocenę użyteczności danej metody w ramach wskazanego obszaru.

\section{Wymiary klasyfikacji dobrych praktyk}

dentyfikacja przekrojów klasyfikacyjnych i wymiarów w obrębie poszczególnych przekrojów została wykonana na podstawie analizy dokumentów normatywnych związanych $\mathrm{z}$ procesem planowania cywilnego i zarzą- 


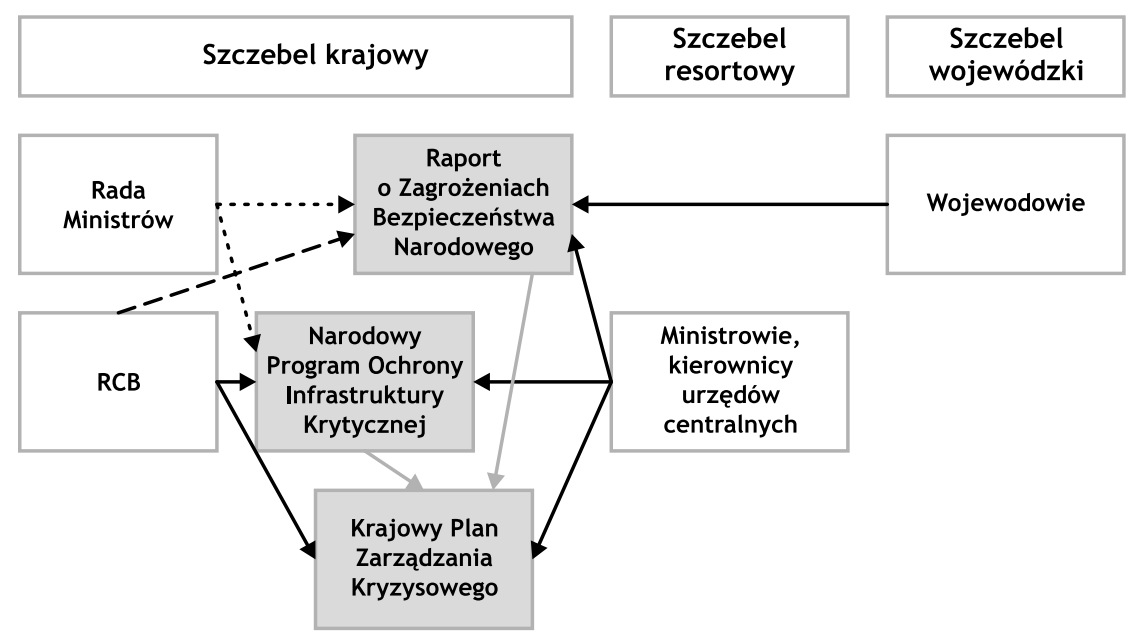

Legenda:

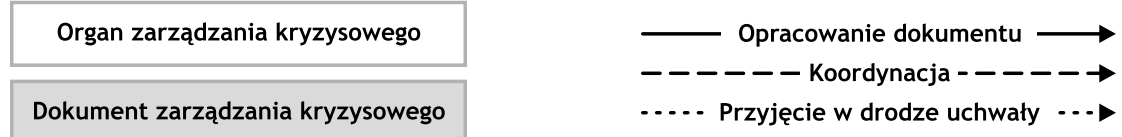

Rys. 1. Powiązania między dokumentami zarządzania kryzysowego na poziomie centralnym Źródło: Kąkol i in., 2017

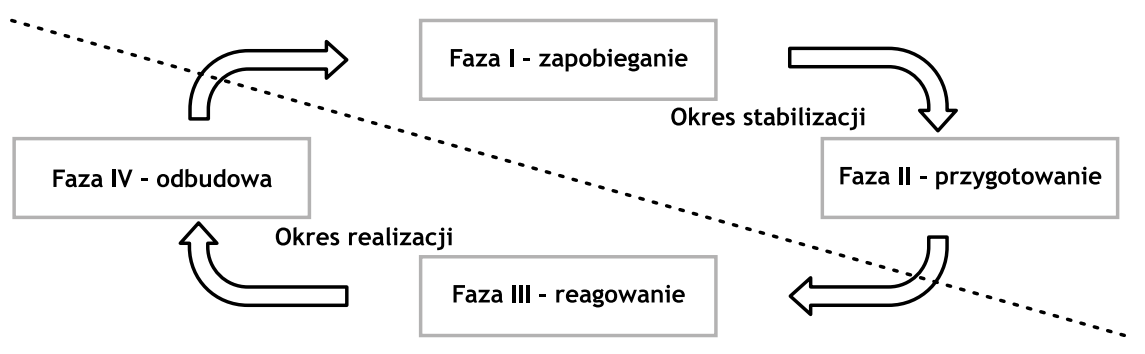

Rys. 2. Proces zarządzania kryzysowego

Źródło: opracowanie własne na podstawie: Ustawa, 2007, poz. 209

dzania kryzysowego (m. in. Dz.Urz. UE. L. 347/924 2013; Ustawa, 2007; RCB, 2010; RCB, 2017). Przyjęto następujące przekroje klasyfikacji dobrych praktyk:

- działania podejmowane w ramach UMOL,

- działania podejmowane $\mathrm{w}$ procesie planowania cywilnego,

- działania podejmowane $\mathrm{w}$ procesie zarządzania kryzysowego,

- działania podejmowane w procesie zarządzania ryzykiem,

- dojrzałość organizacji w obszarze publicznego zarządzania ryzykiem.

W ramach wskazanych przekrojów zostały określone kluczowe wymiary, stanowiące podstawę opisu dobrej praktyki w ramach klasyfikacji.

Stosowany w Polsce proces planowania cywilnego i zarządzania kryzysowego ze względu na członkostwo Polski w UE musi być zgodny z zapisami UMOL, które przedstawiają ogólne zasady działań państw członkowskich podejmowane w obszarze ochrony ludności, zapewnienia bezpieczeństwa publicznego oraz zarządzania kryzysowego. Ochrona ludności w UE obejmuje trzy fazy cyklu zarządzania katastrofami (Dz.Urz.,
2013, art. 5, 8, 15), które przyjęto jako pierwszy wymiar klasyfikacji:

- zapobieganie - której celem są inwestycje w rozwiązania zapobiegawcze występowaniu katastrof,

- gotowość - której celem są działania przygotowawcze podejmowane po to, by umożliwić sprawną mobilizację modułów interwencyjnych w przypadku katastrofy,

- reagowanie - której celem są inwestycje w narzędzia wykorzystywane w przypadku wystąpienia zdarzenia niekorzystnego.

Dokumenty tworzone w procesie planowania cywilnego zostały sprecyzowane $\mathrm{w}$ ustawie o zarządzaniu kryzysowym (Ustawa, 2007, poz. 209) i są ze sobą ściśle powiązane (rys. 1). Są to Krajowy Plan Zarządzania Kryzysowego KPZK, Raport o Zagrożeniach Bezpieczeństwa Narodowego RZBN oraz Narodowy Program Ochrony Infrastruktury Krytycznej NPOIK. Kategorie danych zawarte w RZBN, PZK i NPOIK stanowią drugi wymiar klasyfikacji dobrych praktyk.

Proces zarządzania kryzysowego jest elementem komplementarnym do procesu planowania cywilnego i składa się z okresów: okresu stabilizacji, skupionego 


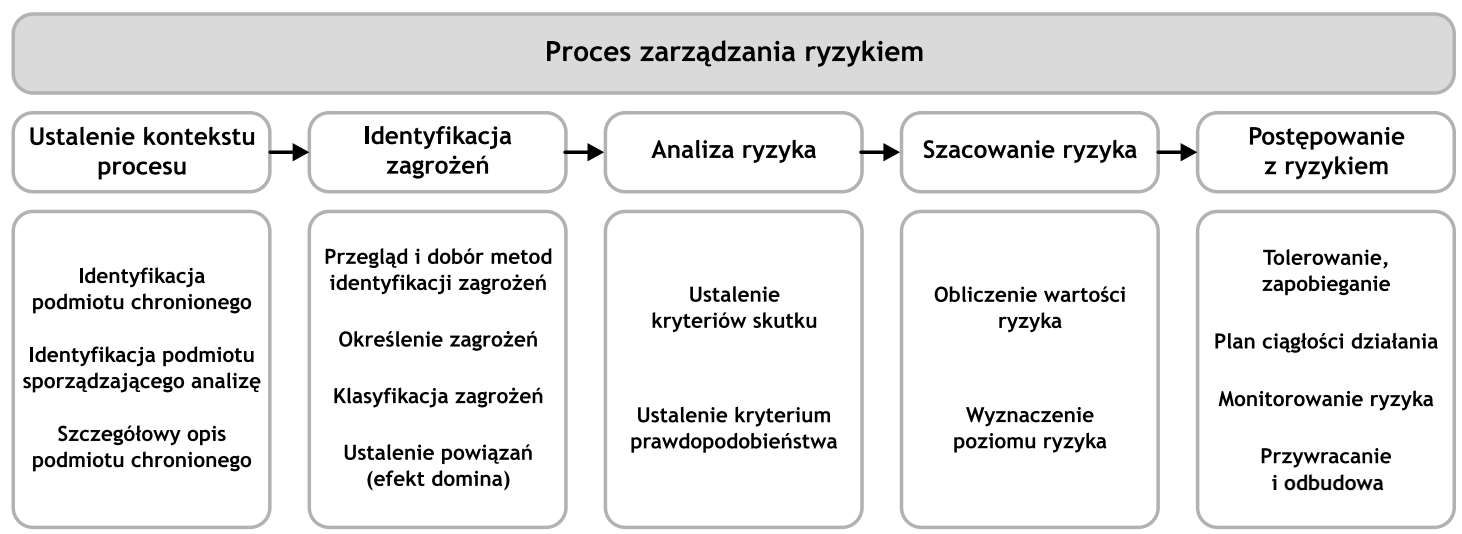

Rys. 3. Schemat procesu zarządzania ryzykiem Źródło: Kosieradzka, Smagowicz, 2018

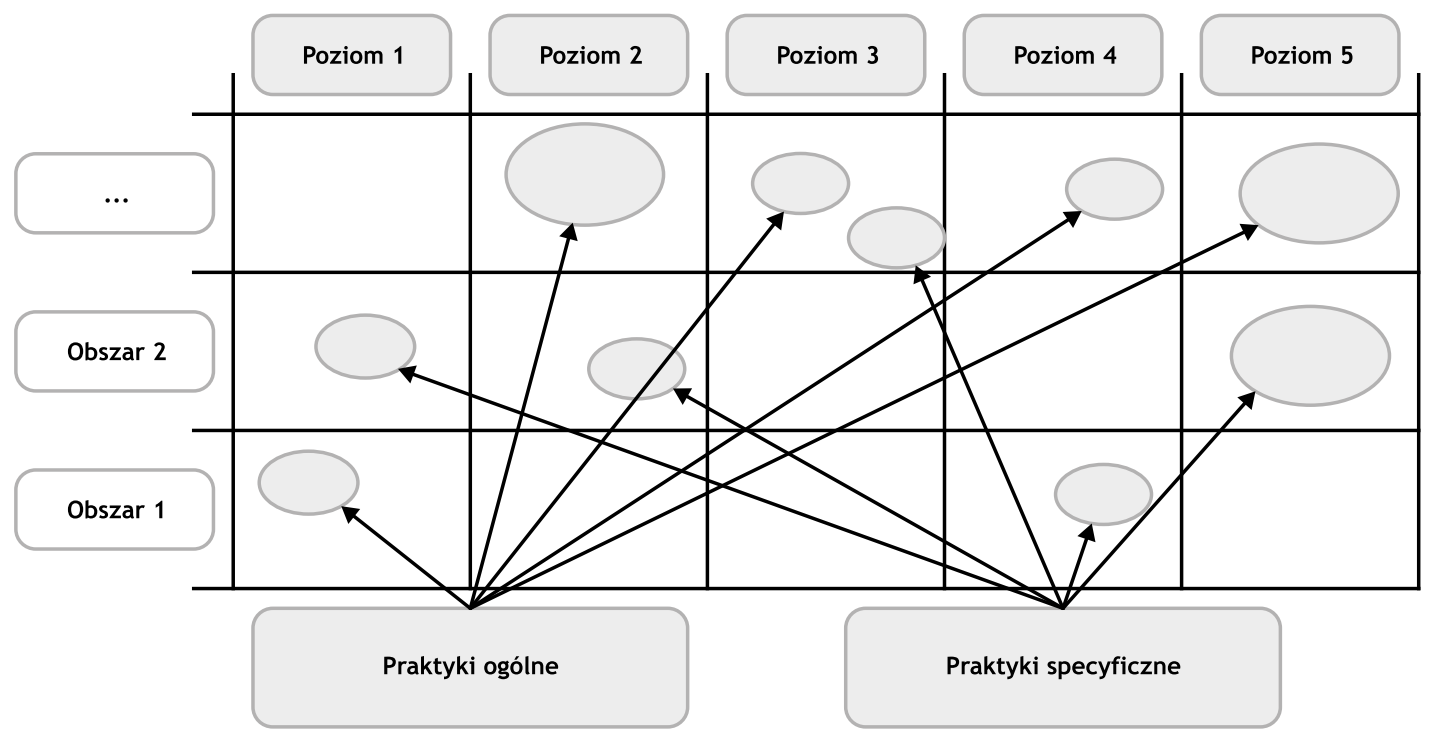

Rys. 4. Struktura modelu dojrzałości w obszarze publicznego zarządzania kryzysowego Źródto: opracowanie wtasne

na zapobieganiu i przygotowaniu do wystąpienia sytuacji kryzysowej, oraz okresu realizacji, koncentrującego się na reagowaniu na wystąpienie sytuacji kryzysowej, a następnie przywróceniu stanu sprzed wystąpienia zagrożenia. Uproszczony schemat procesu zarządzania kryzysowego został przedstawiony na rysunku 2. Wskazane okresy i fazy stanowią trzeci wymiar opisu wzorca dobrych praktyk.

Proces zarządzania ryzykiem w zarządzaniu kryzysowym składa się $\mathrm{z}$ pięciu podprocesów, do których należą (Kosieradzka, Zawiła-Niedźwiecki, 2016, s. 185): ustalenie kontekstu procesu, identyfikacja zagrożeń, analiza ryzyka, szacowanie ryzyka oraz postępowanie z ryzykiem, pokazane w sposób szczegółowy na rysunku 3. Przedstawione podprocesy procesu zarządzania ryzykiem stanowią czwarty wymiar klasyfikacji dobrych praktyk stosowanych w zarządzaniu kryzysowym.

W ramach realizowanego projektu rozwojowego została podjęta próba opracowania modelu dojrzałości organizacji, który będzie wspierał jednostki administracji publicznej w dążeniu do ciągłego podwyższania dojrzałości organizacji do realizacji działań związanych z publicznym zarządzaniem kryzysowym. Szczegółowa koncepcja modelu została przedstawiona w publikacji A. Kosieradzkiej i J. Smagowicz (2018), natomiast ogólna struktura modelu na rysunku 4. Integralną częścią tego modelu jest repozytorium dobrych praktyk, w którym został wprowadzony podział dobrych praktyk na praktyki ogólne i specyficzne. Praktyki ogólne definiowane są jako metody i narzędzia wykorzystywane $\mathrm{w}$ działaniach podejmowanych przez organizację na różnych etapach procesu zarządzania ryzykiem, natomiast praktyki specyficzne definiowane są jako metody i narzędzia, których implementacja odbywa się w ściśle określonym obszarze procesu zarządzania ryzykiem.

Przedstawione kryteria podziału na praktyki ogólne i specyficzne, jak również ich przyporządkowanie do jednego z 5 poziomów dojrzałości, wynikających z budowy modelu (gdzie 1 oznacza poziom najniższy, a 5 oznacza poziom najwyższy) zostały wykorzysta- 
52 | PRZEGLĄD ORGANIZACJI 7/2019

Tabela 2. Zestawienie kryteriów klasyfikacji dobrych praktyk

\begin{tabular}{|c|c|c|}
\hline Przekroje klasyfikacji & Wymiary w ramach przekroju & Atrybut opisu wymiaru \\
\hline \multirow{3}{*}{ UMOL } & \multirow{3}{*}{ Etapy działania podejmowane w UMOL } & Obszar zapobiegania \\
\hline & & Obszar gotowości \\
\hline & & Obszar reagowania \\
\hline \multirow{32}{*}{ Planowanie cywilne } & \multirow{5}{*}{$\begin{array}{l}\text { Poziom działań podejmowanych w procesie } \\
\text { planowania cywilnego }\end{array}$} & Poziom krajowy \\
\hline & & Poziom wojewódzki \\
\hline & & Poziom powiatowy \\
\hline & & Poziom gminny \\
\hline & & Poziom operatora IK \\
\hline & \multirow{6}{*}{$\begin{array}{l}\text { Etapy działań podejmowane w procesie } \\
\text { planowania cywilnego }\end{array}$} & Analizowanie \\
\hline & & Prognozowanie \\
\hline & & Opracowanie planu/programu \\
\hline & & Wdrożenie \\
\hline & & Testowanie \\
\hline & & Uruchamianie \\
\hline & \multirow{3}{*}{ Elementy Planu Zarządzania Kryzysowego } & Plan Główny \\
\hline & & Zespół przedsięwzięć na wypadek sytuacji kryzysowych \\
\hline & & Załączniki funkcjonalne planu głównego \\
\hline & \multirow{7}{*}{$\begin{array}{l}\text { Elementy Raportu o Zagrożeniach } \\
\text { Narodowych }\end{array}$} & Zagrożenia \\
\hline & & Scenariusze \\
\hline & & Analiza skutków \\
\hline & & Ocena ryzyka \\
\hline & & Zapobieganie \\
\hline & & Przygotowanie \\
\hline & & Reagowanie \\
\hline & \multirow{5}{*}{$\begin{array}{l}\text { Elementy Raportu Cząstkowego } \\
\text { o Zagrożeniach Bezpieczeństwa } \\
\text { Narodowego }\end{array}$} & Zagrożenia \\
\hline & & Zapobieganie \\
\hline & & Przygotowanie \\
\hline & & Reagowanie \\
\hline & & Dane historyczne \\
\hline & \multirow{6}{*}{$\begin{array}{l}\text { Elementy Planu Ochrony Infrastruktury } \\
\text { Krytycznej }\end{array}$} & Dane ogólne \\
\hline & & Dane IK \\
\hline & & Charakterystyka zagrożeń \\
\hline & & Charakterystyka zależności \\
\hline & & Charakterystyka zasobów własnych \\
\hline & & Warianty działania w sytuacji zagrożenia \\
\hline
\end{tabular}




\begin{tabular}{|c|c|c|}
\hline Przekroje klasyfikacji & Wymiary w ramach przekroju & Atrybut opisu wymiaru \\
\hline & & Warianty zapewnienia ciągłości działania \\
\hline & & Warianty odtwarzania IK \\
\hline & & Zasady współpracy z centrami zarządzania kryzysowego \\
\hline & & Zasady współpracy z organami administracji publicznej \\
\hline & & Zarządzanie całością działania \\
\hline \multirow{6}{*}{ Zarządzania kryzysowe } & \multirow{2}{*}{$\begin{array}{l}\text { Okresy działań podejmowanych w procesie } \\
\text { zarządzania kryzysowego }\end{array}$} & Okres stabilizacji \\
\hline & & Okres realizacji \\
\hline & \multirow{4}{*}{$\begin{array}{l}\text { Fazy działania podejmowanie w procesie } \\
\text { zarządzania kryzysowego }\end{array}$} & Faza zapobieganie \\
\hline & & Faza przygotowanie \\
\hline & & Faza reagowanie \\
\hline & & Faza odbudowa \\
\hline \multirow{5}{*}{ Zarządzanie ryzykiem } & \multirow{5}{*}{$\begin{array}{l}\text { Etapy działań występujące w procesie } \\
\text { zarządzania ryzykiem }\end{array}$} & Ustalenie kontekstu \\
\hline & & Identyfikacja zagrożeń \\
\hline & & Analiza ryzyka \\
\hline & & Szacowanie ryzyka \\
\hline & & Postępowanie z ryzykiem \\
\hline \multirow{7}{*}{$\begin{array}{l}\text { Model dojrzałości } \\
\text { organizacji }\end{array}$} & \multirow{5}{*}{ Wymiar opisujący poziom dojrzałości } & Poziom 1 \\
\hline & & Poziom 2 \\
\hline & & Poziom 3 \\
\hline & & Poziom 4 \\
\hline & & Poziom 5 \\
\hline & \multirow{2}{*}{$\begin{array}{l}\text { Charakter dobrej praktyki w ramach } \\
\text { obszarów procesowych }\end{array}$} & Praktyka ogólna \\
\hline & & Praktyka specyficzna \\
\hline
\end{tabular}

Źródto: opracowanie własne

ne jako kryteria piątego przekroju klasyfikacyjnego $\mathrm{w}$ opisywanym repozytorium.

\section{Struktura repozytorium dobrych praktyk \\ dla publicznego zarządzania kryzysowego}

0 mówione wymiary klasyfikacji dobrych praktyk posłużyły do budowy koncepcji struktury repozytorium, skupiającego metody możliwe do wykorzystania w publicznym zarządzaniu kryzysowym (rys. 5 i tab. 2).

Podstawowa funkcjonalność repozytorium zakłada, że wybór metody będzie odbywał się poprzez podanie zestawu kryteriów pozwalających na dobranie odpowiedniego narzędzia do założonego celu, np.:

- realizowanego procesu,

- etapu działania w procesie,

- poziomu administracyjnego,

- poziomu dojrzałości organizacji itp.

Należy przypomnieć, że w repozytorium dobre praktyki oprócz wspomnianych wymiarów zostaną opisane według informacji podstawowych stanowiących metrykę metody. Na metrykę składają się: nazwa metody, zakres stosowania, etapy metody, wskazówki stosowania, narzędzia wspomagające, wymagania wstępne i źródło dodatkowych informacji.

Przedstawiony wykaz wymiarów, opisujących dobre praktyki stosowane $\mathrm{w}$ publicznym zarządzaniu 


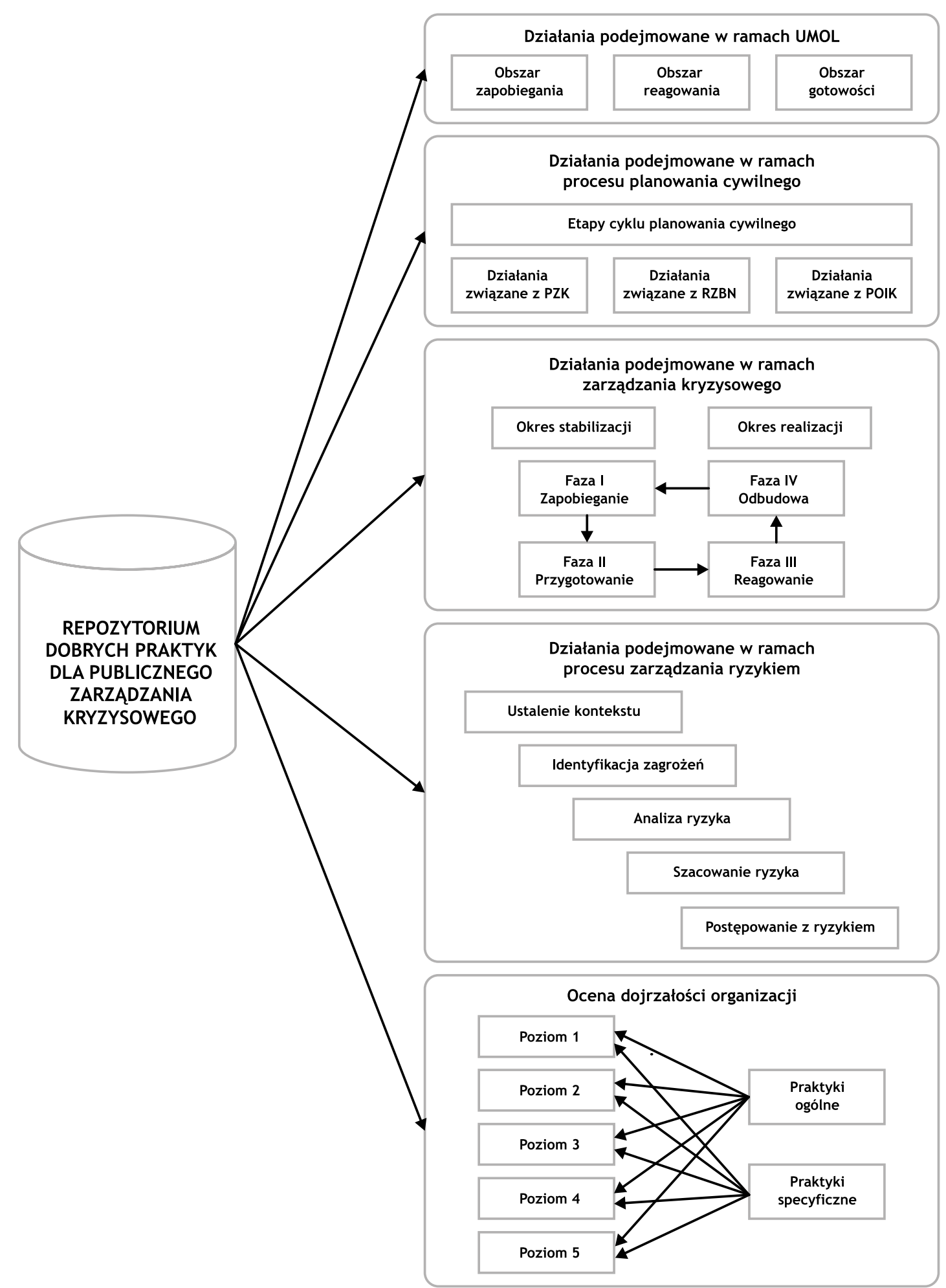

Rys. 5. Struktura repozytorium dobrych praktyk wykorzystywanych w publicznym zarządzaniu kryzysowym Źródto: opracowanie własne 
kryzysowym, należy traktować jako otwarty - oznacza to, że zakres przypisanych praktyk, jak również same kryteria doboru mogą ulegać zmianie w zależności od zmian aktów prawnych, szablonów dokumentów czy realizacji procesów, a także w związku z pojawieniem się nowych metod możliwych do wykorzystania $\mathrm{w}$ dowolnym etapie czy fazie procesu zarządzania kryzysowego.

\section{Podsumowanie}

W edług wiedzy autorów, opracowana koncepcja repozytorium dobrych praktyk dla publicznego zarządzania kryzysowego jest oryginalnym rozwiązaniem ze względu na kompleksowe ujęcie dużego zbioru metod i technik przydatnych do realizacji różnych zadań w ramach publicznego zarządzania kryzysowego oraz próbę ich wieloprzekrojowego uporządkowania. Nie natrafiono także na żadną wzmiankę o wykorzystywaniu podobnego repozytorium $\mathrm{w}$ publicznym zarządzaniu kryzysowym w innych krajach.

Opracowane repozytorium mimo swojej otwartości i kompleksowości ma zastosowanie dla procesów zarządzania kryzysowego i planowania cywilnego realizowanych w Polsce. Ograniczenie to wynika z przyjętej metody projektowania repozytorium, która zakłada, że wymiary przeszukiwania repozytorium wynikają bezpośrednio z porządku prawnego rozpatrywanego kraju. Niemniej struktura repozytorium dobrych praktyk może być dostosowana do uwarunkowań formalnoprawnych dowolnego kraju, co świadczy o uniwersalności wskazanej metody projektowania repozytorium.

Warto zwrócić uwagę, że nie wszystkie metody sklasyfikowane w ramach repozytorium będą wykorzystywane w każdej jednostce samorządu terytorialnego. Wysoki stopień różnorodności jednostek w aspekcie wielkości zajmowanego terytorium, warunków środowiska naturalnego, infrastruktury usług publicznych, poziomu wiedzy i doświadczenia zatrudnionych pracowników, a przede wszystkim posiadanych kompetencji sprawia, że w poszczególnych jednostkach zakres stosowanych metod będzie ograniczony i ściśle powiązany z zakresem prowadzonych działań.

W ramach struktury repozytorium zostały opracowane różne przekroje klasyfikacji dobrych praktyk, umożliwiając osobom odpowiedzialnym za sporządzanie dokumentów wykorzystywanych w publicznym zarządzaniu kryzysowym dobór metod adekwatnych do podejmowanych przez nie działań. Zwykle repozytoria dobrych praktyk dedykowane dla różnych obszarów zarządzania liczą po kilkaset metod i bez odpowiedniego ustrukturyzowania względem wymiarów dobranych do specyfiki obszaru, ich skuteczne wykorzystywanie jest utrudnione. Efektywne wykorzystanie repozytorium wymaga implementacji jego struktury w środowisku cyfrowym, wspomagającym możliwość przeszukiwania repozytorium względem wybranego wymiaru.

\author{
dr hab. inż. Anna Kosieradzka, prof. uczelni \\ Politechnika Warszawska \\ Wydział Zarządzania \\ ORCID: 0000-0001-5157-8126 \\ e-mail: Anna.Kosieradzka@pw.edu.pl
}

\section{mgr inż. Justyna Smagowicz \\ Politechnika Warszawska \\ Wydział Zarządzania \\ ORCID: 0000-0001-7836-5999 \\ e-mail: Justyna.Smagowicz@pw.edu.pl}

\author{
dr inż. Michał Wiśniewski \\ Politechnika Warszawska \\ Wydział Zarządzania \\ ORCID: 0000-0003-3435-3114 \\ e-mail: Michal.Wisniewski@pw.edu.pl
}

\section{Przypis}

1) W artykule wykorzystano dorobek dwóch projektów badawczo-rozwojowych z obszaru planowania cywilnego i zarządzania kryzysowego, finansowanych przez NCBR, realizowanych przez Wydział Zarządzania Politechniki Warszawskiej w latach 2012-2018: „Metodyka oceny ryzyka na potrzeby systemu zarządzania kryzysowego RP" (ID 193751), realizowanego przez konsorcjum w składzie: Szkoła Główna Służby Pożarniczej, Wydział Zarządzania Politechniki Warszawskiej, Wydział Bezpieczeństwa Akademii Obrony Narodowej, Centrum Naukowo-Badawcze Ochrony Przeciwpożarowej im. Józefa Tuliszkowskiego, Medcore Sp. z o.o. oraz projektu pt. „Wysokospecjalistyczna platforma wspomagająca planowanie cywilne i ratownictwo $\mathrm{w}$ administracji publicznej RP oraz w jednostkach organizacyjnych KSRG" realizowanej w ramach konsorcjum Politechnika Warszawska Wydział Zarządzania oraz Medcore Sp. z o.o. (Umowa nr DOB-BIO7/11/02/2015).

\section{Bibliografia}

[1] Bogan Ch.E., English M.J. (1994), Benchmarking of Best Practices, McGraw-Hill, New York.

[2] Camp R.C. (1989), Benchmarking: The Search For Industry Best Practices That Lead to Superior Performance, ASQC Ouality Press, Milwaukee.

[3] Chrapko M. (2010), CMMI. Doskonalenie procesów w organizacji, Wydawnictwo Naukowe PWN, Warszawa.

[4] Chrissis M.B., Konrad M., Shrum S. (2003), CMMI Guidelines for Process Integration and Product Improvement, Addison-Wesley, Boston.

[5] Cyfert S., Szumowski W. (2015), Dobre praktyki zarzadzania w administracji samorządowej, „Nauki o Zarządzaniu Management Sciences", Nr 4(25), s. 28-37.

[6] Decyzja Parlamentu Europejkkiego i Rady nr 1313/2013/ EU z dnia 17 grudnia 2013 r. w sprawie Unijnego Mechanizmu Ochrony Ludności UMOL, Dz.Urz. UE. L. 347/924 z 20.12.2013., https://www.prawo.pl/akty/dz-u-ue-1-2013-347-924,68384708.html, access date: 22.05.2018. 
[7] Internetowy Słownik Języka Polskiego SJP, https://sjp.pl/ repozytorium, data dostępu: 27.08.2019 r.

[8] Karwińska A., Wiktor D. (2008), Przedsiębiorczość i korzyści społeczne: identyfikacja dobrych praktyk $w$ ekonomii społecznej, „Ekonomia Społeczna”, Nr 6, s. 6-8.

[9] Kąkol U., Smagowicz J., Uklańska A. (2017), Koncepcja metodyki analizy i oceny dla zagrożeń oraz ryzyka $z$ perspektywy administracji centralnej, „Studia i Materiały. Miscellanea Oeconomicae", Nr 4, s. 351-366.

[10] Kąkol U., Smagowicz J. (2018). Systematyka dobrych praktyk wykorzystywanych $w$ publicznym zarzadzaniu kryzysowym, „Nowoczesne Systemy Zarządzania”, Nr 13, s. 31-45.

[11] Kosieradzka A. (2012), Zarządzanie produktywnością $w$ przedsiębiorstwie, C.H. Beck, Warszawa.

[12] Kosieradzka A. (2013), Metody i techniki pobudzania kreatywności $w$ organizacji i zarządzaniu, Edu-Libri, Kraków-Warszawa.

[13] Kosieradzka A., Smagowicz J. (2018), Model dojrzałości organizacji w obszarze publicznego zarzadzania kryzysowego, Zeszyty Naukowe Politechniki Śląskiej, seria Organizacja i Zarządzanie z. 128, s. 217-230.

[14] Kosieradzka A., Zawiła-Niedźwiecki J. (2016), Zaawansowana metodyka oceny ryzyka w publicznym zarzadzaniu kryzysowym, Edu-Libri, Kraków-Legionowo.

[15] Krupa T., Wiśniewski M. (2015), Situational Management of Critical Infrastructure - Resources United Threat, „Foundations of Management”, Vol. 7, s. 93-104.

[16] Lidwa W. (2015), Zarzadzanie kryzysowe, AON, Warszawa.

[17] Lis S. (red.), (1999), Vademecum produktywności, Placet, Warszawa.

[18] Lunau S. (red.), (2008), Six Sigma + Lean Toolset, Springer-Verlag, Berlin, Heidelberg.

[19] Martyniak Z. (1996), Metody organizowania procesów pracy, PWE, Warszawa

[20] Mikołajczyk Z. (2001), Techniki organizatorskie $w$ rozwiązywaniu problemów zarządzania, Wydawnictwo Naukowe PWN, Warszawa.

[21] OMG (2008), BPMM - Business Process Maturity Model, OMG, Needham, June 2008, https://www.omg.org/spec/ BPMM/About-BPMM/, access date: 22.05.2018.

[22] Ostrowska T., Wiśniewski M. (2016), Wyzwania i dobre praktyki zarzadzania bezpieczeństwem infrastruktury krytycznej, [w:] M. Ćwiklicki, M. Jabłoński, S. Mazur (red.), Współczesne koncepcje zarządzania publicznego, Fundacja Gospodarki i Administracji Publicznej, Kraków, s. 111-125.

[23] PMI (2003), OPM3 - Organizational Project Management Maturity Model, PMI, Newton Square, Pennsylvania.

[24] RCB (2010), Procedura opracowania raportu czastkowego do raportu o zagrożeniach bezpieczeństwa narodowego, http://rcb.gov.pl/wp-content/uploads/procedura.pdf, data dostępu: 30.07.2019 r.

[25] RCB (2017), Krajowy Plan Zarzadzania Kryzysowego 2017, http://rcb.gov.pl/krajowy-plan-zarzadzania-kryzysowego/, data dostępu: 30.07.2019 r.
[26] Skomra W. (red.), (2015), Metodyka oceny ryzyka na potrzeby systemu zarządzania kryzysowego RP, Bel Studio Sp. z o.o., Warszawa.

[27] Skomra W. (2017), Zarządzanie ryzykiem operacyjnym $w$ administracji publicznej, „Przegląd Organizacji”, Nr 9, s. $40-45$.

[28] Słownik Języka Polskiego PWN, https://sjp.pwn.pl/szukaj/praktyka.html, data dostępu: 27.08.2019 r.

[29] Szczepańska K. (2009), Metody i techniki TQM, Oficyna Wydawnicza Politechniki Warszawskiej, Warszawa.

[30] Tyburska A. (2009), Ochrona infrastruktury krytycznej - potrzeby edukacyjne, [w:] T. Białas, M. Grzybowski, J. Tomaszewski (red.), Zarzadzanie bezpieczeństwem w sektorze publicznym i biznesie, Wyd. Wyższej Szkoły Administracji i Biznesu im. E. Kwiatkowskiego, Gdynia, s. 83-102.

[31] Wiśniewski M., Kunikowski G., Kisilowski M. (2017), Koncepcja metodycznego gromadzenia wzorców i przykładów dobrych praktyk z zakresu planowania cywilnego oraz budowy planów ratowniczych i planów zarządzania kryzysowego, Studia i Materiały „Miscellanea Oeconomicae", Vol. 4, tom I, s. 307-320.

[32] Zawiła-Niedźwiecki J., Kisilowski M. (2016), Poszukiwanie nowego paradygmatu publicznego zarzadzania kryzysowego, „Przegląd Organizacji”, Nr 3, s. 49-56.

[33] Ustawa $z$ dnia 26 kwietnia 2007 r. o zarządzaniu kryzysowym z późn. zm., tekst jedn. Dz.U.2018.0.1401, http:// prawo.sejm.gov.pl/isap.nsf/DocDetails.xsp?id=WDU20070890590/, data dostępu: 17.06.2018 r.

[34] Wikipedia - Wolna Encyklopedia https://pl.wikipedia. org/wiki/Repozytorium, data dostępu: 27.08.2019 r.

\section{The Concept of a Repository of Best Practices Used in Public Crisis Management}

\section{Summary}

This article presents a methodical approach to building a best practices repository on the example of a case study for the public crisis management. The results of the development project led to the identification of key dimensions for classifying best practices collected in the repository, determination of the description (metric) of any best practice qualified to the repository in conjunction with the process of civil planning, crisis management and risk management, as well as building the maturity of the organisation. The approach described in the article is universal - it can be used to build a repository of best practices for other areas of management. The concept of repository structure is prepared to be implemented in a digital environment.

\section{Keywords}

best practices, public crisis management, repository, risk management 